\title{
PENGARUH PUPUK NPK PELANGI TERHADAP PERTUMBUHAN DAN HASIL TANAMAN MENTIMUN (Cucumis sativus L.)
}

\author{
Nikolaus Bernardus Odiluda ${ }^{1}$, Josina I. B. Hutubessy ${ }^{2}$ \\ Dosen Program Studi Agroteknologi Fakultas Pertanian Universitas Flores \\ Jl. Sam Ratulangi-Paupire, Ende-Flores, NTT \\ irenehutubessy91@yahoo.co.id
}

\begin{abstract}
The study aimed to determine the effect of NPK Pelangi fertilizer on the growth and yield of cucumber and its optimum dosage.

This study uses a Randomized Block Design (RBD). The treatments are Po: Rainbow NPK Fertilizer $0 \mathrm{~kg}$ ha-1 (control); P1: NPK Pelangi Fertilizer $300 \mathrm{~kg}$ ha-1 = $150 \mathrm{gr}$ plot-1; P2: Rainbow NPK fertilizer $600 \mathrm{~kg}$ ha-1 = 300 gr plot-1; P3: Rainbow NPK Fertilizer $900 \mathrm{~kg}$ ha-1 = 450 gr plot-1; P4: Rainbow NPK Fertilizer $1200 \mathrm{~kg}$ ha- $1=600$ gr plot-1.

The results showed that NPK Pelangi fertilizer had a very significant effect on leaf average $(11.89 \%)$, leaf area-1 $(12.85 \%)$, number of fruit tan-1 $(26.37 \%)$, fruit length $\tan -1$ (4 , 42\%), diameter of fruit tan-1 (8.77\%), weight of fruit tan-1 (30.33\%), weight of fruit ha-1 $(30.33 \%)$.

The optimum dose of NPK Pelangi fertilizer is 1,200 kg ha-1 because it provides optimal growth and yield on the number of leaves (15,13 strands) of leaf area-1 (420.69 $\left.\mathrm{cm}^{2}\right)$, number of fruit tan-1 (7.13 pieces), length of fruit tan-1 $(17.21 \mathrm{~cm})$, diameter of tan-1 fruit (15.13 mm), weight of fruit tan-1 (2492.75 grams), weight of fruit ha-1 (99.71 tons).
\end{abstract}

Key words : NPK Pelangi fertilizer, cucumber.

\section{PENDAHULUAN}

Mentimun (Cucumis sativus L.) merupakan salah satu jenis sayuran dari keluarga labu -labuan (Cucurbitaceae) yang sudah pupuler di dunia.Menurut sejarah tanaman mentimun berasal dari Benua Asia.Beberapa sumber literatur menyebutkan daerah asal tanaman mentimun adalah Asia Utara,tetapi sebagian lagi menduga berasal dari Asia Selatan (Rukmana, 1994). Pembudidayaan mentimun meluas seluruh dunia, baik daerah beriklim panas (tropis) maupun di daerah beriklim sedang (sub tropis).Di
Indonesia tanaman mentimun ditanam di daerah daratan rendah dan dataran tinggi 0-1000 meter di atas permukaan laut.

Buah mentimun memiliki bermacam-macam manfaat dalam kehidupan sehari-hari, antara lain sebagai bahan makanan, bahan untuk obat-obatan dan bahan kosmetik. Nilai gizi mentimun cukup baik karena sayuran buah ini merupakan sumber mineral dan vitamin. Buah mentimun mengandung zat-zat saponin, protein, lemak, kalsium, fosfor, besi, belerang, vitamin A, B1, dan C. Mentimun 
mentah bersifat menurunkan panas badan, juga meningkatkan stamina. Kandungan 100 g mentimun terdiri dari 15 kalori, 0,8 g protein, 0,19 g pati, $3 \mathrm{~g}$ karbohidrat, $30 \mathrm{mg}$ fosfor, $0,5 \mathrm{mg}$ besi, $0,02 \mathrm{~g}$ tianin, $0,05 \mathrm{~g}$ riboflavin, $14 \mathrm{mg}$ asam (Sumpena, 2001).

Menurut Direktorat Jenderal Hortikultura 2015 secara nasional, produktifitas tanaman mentimun pada tahun 2015 yaitu 48,578 ton/hektar. Mengalami penurunan jika dibandingkan dengan produksi pada tahun 2014 yaitu sebesar 49,296 ton/hektar (Badan Pusat Statistik dan Direktorat Jenderal Hortikultura 2015). Sementara itu hasil mentimun di NTT pada tahun 2014 dengan luas lahan 50,8 ha produksi dapat mencapai 70,4 ton sehingga produktivitasnya 1,39 ton/ha. Pada tahun 2015, dengan luas lahan yang sama mengalami penurunan dengan produksi mencapai 64,14 ton dan produktivitas 1,29 ton/ha (Dinas Pertanian Tanaman Pangan dan Hortikultura NTT 2015). Data yang diperoleh dari Dinas Pertanian Tanaman Pangan dan Hortikultura Kabupaten Ende tahun 2015 produksi mentimun pada tahun 2015 dengan luas lahan 17 ha dan luas panen 15 ha mencapai 20 ton dan produktivitas 1,18 ton/ha.

Rendahnya produktivitas tanaman mentimun di Indonesia juga dapat disebabkan oleh beberapa faktor di antaranya adalah faktor iklim, teknik bercocok tanam seperti pengolahan tanah, pemupukan, pengairan, serta adanya serangan hama dan penyakit (Sumpena, 2001).

Penggunaan pupuk sebagai bahan tambahan dalam meningkatkan pertumbuhan dan produksi mentimun. Untuk itu pemupukan sangat penting bagi tanaman mentimun, sehingga unsur hara yang diperlukan tersedia di dalam tanah. Pemupukan dapat dilakukan dengan memperhatikan jenis pupuk yang digunakan. Anjuran pupuk yang dipakai petani adalah dengan menggunakan pupuk NPK dengan dosis 40 gr/tanaman. Jenis pupuk yang digunakan yaitu pupuk NPK Pelangi. Mentimun membutuhkan unsur N, P, K, dan $\mathrm{Ca}$ dalam jumlah yang cukup dan hal tersebut dapat dipenuhi melalui usaha pemupukan dan pemberian kapur (PT. PUPUK KALTIM, 2005).

Pupuk NPK Pelangi merupakan pupuk majemuk yaitu pupuk yang mengandung lebih dari satu unsur hara yang digunakan untuk menambah kesuburan tanah. Pupuk majemuk NPK Pelangi, yaitu jenis pupuk yang mengandung unsur hara makro Nitrogen, Phospor dan Kalium, kandungan haranya 15\% N, 15\% P2O5, dan $15 \%$ K2O. (Saeri Mohamad dan Suwono 2012)

Selain itu, pupuk NPK Pelangi mempunyai beberapa manfaat diantaranya mempercepat pertumbuhan tanaman, pembentukan anakan, tinggi tanaman, lebar daun, panjang malai dan jumlah gabah, menjadikan daun tanaman lebih hijau sehingga menjamin berlangsungnya proses fotosintesis dengan baik, merangsang pertumbuhan akar tanaman, menjadikan batang tanaman lebih kokoh sehingga mengurangi resiko rebahnya tanaman, meningkatkan ketahanan tanaman terhadap serangan hama dan penyakit, memacu pembungaan, pembentukan 


\section{Josina : Pengaruh Pupuk NPK Pada Tanaman Mentimun}

dan pemasakan biji/buah sehingga biji/buah lebih cepat panen, meningkatkan kandungan protein, gula dan minyak/lemak tanaman, memperbesar ukuran biji,buah dan umbi yang dipanen (Sunarjono, H, H. 2007).

Kelebihan pupuk NPK Pelangiyaitu hanya dengan satu kali pemberian pupuk dapat mencakup beberapa unsur hara sehingga lebih efisien dalam penggunaan bila dibandingan dengan pupuk tunggal. MenurutSuwarno, V. Salsabila (2013), menunjukan bahwa pemberian dosis $600 \mathrm{~kg} / \mathrm{ha}$ NPK Pelangipada tanaman mentimun memberikan pengaruh terhadap peningkatan pertumbuhan dan hasil tanaman mentimun yaitu, rata-rata umur berbunga 28,67 hari, jumlah buah 5,89 buah per tanaman,berat buah 828,60 gram per tanaman, dan berat buah 33,144 ton/ha.Tujuan Penelitian untuk mengetahui pengaruh pemberian pupuk NPK Pelangiterhadap pertumbuhan dan hasil tanaman mentimun dan untuk mengetahui dosis optimum pupuk NPK Pelangidalam meningkatkan pertumbuhan dan hasil tanaman mentimun.

\section{BAHAN DAN METODE}

Penelitian ini dilaksanakan di Kelurahan Onelako, Kecamatan Ndona, Kabupaten Ende. Waktu penelitian \pm 6 (tiga) bulantahun 2016. Dengan ketinggian tempat $500 \mathrm{mdpl}$, kelembabapan $30 \%$, suhu $30-32^{\circ} \mathrm{C}, \mathrm{Ph}$ tanah 5,6 jenis tanah lempung (Ga'a, G. Inarno, 2014).

Bahan yang digunakan adalah; benih tanaman mentimun Hibrida F1 Mercy,pupuk NPK Pelangi.Alat-alat yang digunakan adalah; pacul, skop, sabit, ajir, ember plastik, plastik gula, timbangan, meteran, penggaris, tali rafia, alat tulis dan kamera.

Rancangan yang digunakan dalam percobaan ini adalah Rancangan Acak Kelompok (RAK) dengan pola faktor tunggal yang terdiri dari lima (5) perlakuan dengan dosis pupuk yang berbeda dan diulang sebanyak 4 kali, sehingga terdapat 20 satuan percobaan dimana masing-masing perlakuan terdapat 20 tanaman.Sehingga dalam penelitian ini terdapat 400 tanaman. Adapun perlakuan pada penelitian ini adalah sebagai berikut :

NPKo : Pupuk NPK Pelangi0 kg ha $^{-1}$ (kontrol)

$\mathrm{NPK}_{1}$ : PupukNPK Pelangi300 kg ha $^{-1}=150$ grpetak $^{-1}$

$\mathrm{NPK}_{2}$ : Pupuk NPK Pelangi600 $\mathrm{kg} \mathrm{ha}^{-1}=300$ gr petak $^{-1}$

$\mathrm{NPK}_{3}$ : Pupuk NPK Pelangi900 $\mathrm{kg} \mathrm{ha}^{-1}=450$ gr $_{\text {petak }}{ }^{-1}$

$\mathrm{NPK}_{4}$ : Pupuk NPK Pelangi1200 $\mathrm{kg} \mathrm{ha}^{-1}=600$ gr petak $^{-1}$

Pupuk dasar diaplikasikan setelah pembuatan bedengan dengan menggunakan pupuk organikPetroganik sebanyak $10 \mathrm{~kg}$ (20 ton/ha) pada setiap perlakuan. Aplikasidosis pupuk NPK Pelangidilakukan pada saat tanaman mentimun berumur 14 hst dan 30 hst, dengan masing-masing setengahdari dosis setiap perlakuan. Pengaplikasian pupuk NPK Pelangi dengan cara melarutkan setiap dosis pupuk NPK setiap aplikasi dengan 5 liter air.

Panen buah pertama dapat dipetik setelah umur 55 hst, panen dapat dilakukan sampai 3 kali dengan interval 7 hari sekali. 
Variabel

Pengamatan

pertmbuhanberumur 7 hst, 14 hst, 21 hst, dan 28 hstpada jumlah daun Tan ${ }^{1}$ (helai) dan luas Daun $\left(\mathrm{cm}^{2}\right)$, luas daun diukur pada semua daun tanaman sampel dengan metode milimetri,sehingga luas daun dapat dihitung dengan cara :Rumus: $L D=$ Jumlah Kotak $\times$ Luas Kota

Variabel Hasil adalah Jumlah Buah Tan ${ }^{1}$ (buah), Panjang Buah Tan ${ }^{1}(\mathrm{~cm})$, Diameter Buah Tan ${ }^{1}(\mathrm{~cm})$, Berat Buah Tanaman $^{1}$ (gr) dan Berat Buah ha ${ }^{1}$ (ton), Berat segar buah per ha dapat dihitung dengan cara berat buah per tanaman $\mathrm{x}$ populasi per hektar $(40.000$ tanaman).

Data yang dikumpulkan dianalisis dengan menggunakan analisis sidik Variabel Pertumbuhan

Berdasarkan hasil analisis sidik ragam menunjukan bahwa pemberian pupuk NPK Pelangi terhadap pertumbuhan dan hasil tanaman ragam sesuai dengan rancangan yang digunakan.Apabilaperlakuan menunjukan pengaruh yang nyata atau sangat nyata terhadap variabelyang diamati, maka pengujian dilanjutkan dengan uji nilai beda rata-rata menggunakan uji BNT 5\%(Gomez dan Gomez, 2007).

\section{HASIL DAN PEMBAHASAN}

Berdasarkan hasil analisis statistik pada tabel signifikansi menunjukkan bahwa pemberian pupuk NPK Pelangimemberikan pengaruh yang sangat nyata terhadap semua variabel pengamatan pada jumlah daun tan 1, luas daun $\tan { }^{1}$, jumlah buah $\tan { }^{1}$, panjang buah tan 1, diameter buah tan ${ }^{1}$, berat buah tan ${ }^{1}$, Berat buah ha ${ }^{1}$. mentimun memberikan pengaruh yang sangat nyata terhadap pertumbuhan jumlah daun dan luas daun pada tanaman mentimun yang dapat dilihat pada tabel 2 sebagai berikut:

Tabel 2 Pengaruh Pupuk NPK Pelangi Terhadap Jumlah Daun dan Luas Daun Tanaman Mentimun.

\begin{tabular}{|c|c|c|c|c|c|c|c|c|c|}
\hline \multirow{2}{*}{ Variabel } & \multirow{2}{*}{ Perlakuan } & \multicolumn{8}{|c|}{ Umur Pengamatan (Hst) } \\
\hline & & 7 & & 14 & & 21 & & 28 & \\
\hline \multirow{5}{*}{$\begin{array}{l}\text { Jumlah Daun } \\
\text { (helai) }\end{array}$} & NPK 0 & 2,00 & $\mathrm{~b}$ & 4,38 & $\mathrm{c}$ & 6,00 & $\mathrm{D}$ & 9,31 & $\mathrm{~d}$ \\
\hline & NPK 1 & 2,00 & $\mathrm{~b}$ & 4,56 & $\mathrm{bc}$ & 8,31 & $\mathrm{C}$ & 13,31 & $\mathrm{bc}$ \\
\hline & NPK 2 & 2,00 & $\mathrm{~b}$ & 4,94 & $\mathrm{~b}$ & 8,50 & B & 13,56 & $\mathrm{~b}$ \\
\hline & NPK 3 & 2,00 & $\mathrm{~b}$ & 5,13 & b & 8,81 & B & 13,64 & $\mathrm{~b}$ \\
\hline & NPK 4 & 2,75 & $\mathrm{a}$ & 5,88 & $\mathrm{a}$ & 9,81 & A & 15,13 & $\mathrm{a}$ \\
\hline BNT 5\% & & 0,34 & & 0,44 & & 0,41 & & $\mathbf{0 , 4 1}$ & \\
\hline \multirow{5}{*}{$\begin{array}{l}\text { Luas Daun } \\
\qquad\left(\mathrm{cm}^{2}\right)\end{array}$} & NPK 0 & 12,38 & $\mathrm{c}$ & 59,91 & $\mathrm{c}$ & 104,67 & $\mathrm{C}$ & 186,80 & $\mathrm{c}$ \\
\hline & NPK 1 & 12,53 & $\mathrm{bc}$ & 60,14 & b & 217,81 & B & 368,70 & $\mathrm{~b}$ \\
\hline & NPK 2 & 12,67 & $\mathrm{~b}$ & 60,21 & $\mathrm{~b}$ & 228,63 & B & 370,33 & $\mathrm{~b}$ \\
\hline & NPK 3 & 12,75 & $\mathrm{~b}$ & 60,31 & $\mathrm{~b}$ & 231,16 & B & 372,48 & $\mathrm{~b}$ \\
\hline & NPK 4 & 13,00 & $\mathrm{a}$ & 60,72 & $\mathrm{a}$ & 282,08 & A & 420,69 & $\mathrm{a}$ \\
\hline BNT 5\% & & $\mathbf{0 , 2 2}$ & & $\mathbf{0 , 3 8}$ & & 19,73 & & 14,94 & \\
\hline
\end{tabular}

Keterangan: Angka yang diikuti oleh huruf yang sama pada kolom yang sama menunjukan tidak berbeda nyata pada taraf 5\% uji BNT 


\section{Josina : Pengaruh Pupuk NPK Pada Tanaman Mentimun}

Hasil analisis sidik ragam (Tabel 2) menunjukan bahwa peningkatan pemberian pupuk NPK Pelangidiikuti oleh peningkatan pada pertumbuhan jumlah daun dan luas daun pada tanaman mentimun. Rataan total pertumbuhan pada jumlah dauntanaman mentimun dari NPK0 (control ) ke NPK1 (300 kg/ha) adalah 23,03 \%, NPK1 ke NPK2 (600 kg/ha)2,83\%, NPK2 ke NPK3 (900 kg/ha) 1,96\%, NPK3 keNPK4(1.200 kg/ha) 11,89\%. Pada data luas daun pemberian pupuk NPK Pelangi juga memberikan pengaruh yang sangat nyata dengan rataan total NPK0 (control) ke NPK1 (300 kg/ha) adalah 44,82\%, NPK1 ke NPK2 (600 kg/ha) 1,88 \%, NPK2 keNPK3 (900 kg/ha)0,72 \%,NPK3 keNPK4(1.200 kg/ha) 12,85 \%. Peningkatan prosentase rataan total pada variabel pertumbuhan jumlah daun dan luas daun mentimun menunjukan bahwa pemberian pupuk NPK Pelangi memberikan pengaruh yang positif pada pertumbuhan tanaman mentimun, karena pupuk NPK Pelangidapat memberikan peningkatan pertumbuhan pada tanaman mentimun. Hal ini disebabkan karena adanya unsur hara yang terdapat dalam pupuk NPK Pelangi (N, P ,K, MgO, Bo, dan Ca) yang dapat membantu mempercepat proses pertumbuhan pada tanaman.Peningkatan dosis pupuk NPK Pelangiyang diberikan, juga akan meningkatkan jumlah unsur hara yang dapat dimanfaatkan oleh tanaman mentimun.

Menurut Sunarjono (2007),pupuk NPK Pelangi mengandung unsur hara makro Nitrogen, Phospor, dan Kalium yang sangat dibutuhkan tanaman. Kandungan hara N, P dan $\mathrm{K}$ dalam 50 kg pupuk NPK Pelangi adalah $15 \% \mathrm{~N}$, $15 \% \mathrm{P}$, dan $15 \% \mathrm{~K}$.

Hasil analisis sidik ragam juga menunjukan bahwa jumlah daun dan luas daun terjadi perbedaan yang nyata. Hal ini dapat terjadi karena kandungan unsur hara $\mathrm{N}$ pada dosis perlakuan NPK2 (600 kg ha ${ }^{-1}=300 \mathrm{gr}$ petak $^{-1}=$ $150 \mathrm{gr} /$ petak/aplikasi) tersebut hanya sedikit sekali yaitu N (90 kg/ha), P (90 $\mathrm{kg} / \mathrm{ha}), \mathrm{K}$ (90 kg/ha), ditambah dengan pupuk organik Petroganik 20 ton/ha yang kandungan unsur haranya $\mathrm{N}=0,40$ $\%, \mathrm{P}=0,10 \%$, dan $\mathrm{K}=0,10 \%$ setara dengan $\mathrm{N}=80 \mathrm{~kg} / \mathrm{ha}, \mathrm{P}=20 \mathrm{~kg} / \mathrm{ha}$, dan $\mathrm{K}=20 \mathrm{~kg} / \mathrm{ha}$, total dari unsur hara yang diberikan adalah $\mathrm{N}=170 \mathrm{~kg} / \mathrm{ha}, \mathrm{P}=110$ $\mathrm{kg} / \mathrm{ha}$, dan $\mathrm{K}=110 \mathrm{~kg} / \mathrm{ha}$, masih sangat rendah dibandingkan dengan kebutuhan unsur hara makro yang dibutuhkan oleh tanaman mentimun yaitu N (300 $\mathrm{kg} / \mathrm{ha}), \quad \mathrm{P}$ (200 kg/ha) dan K (200 $\mathrm{kg} / \mathrm{ha}$ )(Rukmana, 1994).

Sedangkan dosis $1200 \mathrm{~kg} / \mathrm{ha}$ yang setara dengan $\mathrm{N}=180 \mathrm{~kg} / \mathrm{ha}, \mathrm{P}=180$ $\mathrm{kg} / \mathrm{ha}$, dan $\mathrm{K}=180 \mathrm{~kg} / \mathrm{ha}$ dan jika ditambah dengan unsur hara dari pupuk Petroganikmaka N = $260 \mathrm{~kg} / \mathrm{ha}, \mathrm{P}=200$ $\mathrm{kg} / \mathrm{ha}$ dan $\mathrm{K}=200 \mathrm{~kg} / \mathrm{ha}$ sehingga memberikan pengaruh yang sangat nyata terhadap pertumbuhan dan hasil tanaman mentimun memberikan pertumbuhan yang paling optimal yaitu jumlah daun $15,13 \mathrm{~cm}$ dan luas daun $420,69 \mathrm{~cm}^{2}$.

Rendahnya kandungan unsur hara tersebut khususnya pada Nitrogen akan sangat mempengaruhi pertumbuhan pada tanaman. Menurut Paian Simanungkalit dkk (2013) adanya unsur 
nitrogen (N) akan meningkatkan petumbuhan bagian vegetatif seperti daun. Hal ini sesuai dengan pendapat Lingga (2003), bahwa peranan utama nitrogen bagi tanamanadalah untuk merangsang pertumbuhan secara keseluruhan khususnya batang, cabang dan daunyang akan diikuti oleh kesuburan vegetatif dan generatif tanaman.

Hal ini juga senada dengan Gardner, F.P., R.B dkk., 1991, bahwa proses fisiologis didalam tubuh tanaman tidak akan berjalan dengan baik apabila unsur hara tidak tersedia dalam jumlah yang memadai, terutama unsur hara yang berperan dominan dalam pertumbuhan vegetatif tanaman seperti unsur Nitrogen.

\section{Variabel Hasil}

Berdasarkan hasil analisis sidik ragam pada tabel 3 menunjukan bahwa pemberian pupuk NPK Pelangi memberikan pengaruh yangsangat nyata terhadap semua variabel hasil.
Dari hasil pengamatan dapat diketahui bahwa Peningkatan pemberian dosis pupuk NPK Pelangidapat meningkatkan jumlah buah $\tan ^{-1}$, panjang buah $\tan ^{-1}$, diameter buah $\tan ^{-1}$, berat buah $\tan ^{-1}$ dan berat buah $\mathrm{ha}^{-1}$. Rataan total semua variabel hasil secara berturut turut dari NPK0 (control) ke NPK1 (300 kg/ha) adalah $15,70 \%, 3,63 \%, 3,87 \%, 42,42 \%$, $42,41 \%$, NPK1 ke NPK2 (600 $\mathrm{kg} / \mathrm{ha}) 15,78 \%, 6,29 \%, 6,14 \%, 26,83$ $\%, 26,83 \%$, NPK2 keNPK3 (900 $\mathrm{kg} / \mathrm{ha}) 17,90 \%, 3,40 \%, 5,98 \%, 21,61$ $\%, 21,61 \%$, NPK3 keNPK4(1.200 $\mathrm{kg} / \mathrm{ha}) 26,37 \%, 4,42 \%, 8,77 \%, 30,33$ $\%$, 30,33 \%. Hal ini membuktikan bahwa peningkatan dosis pupuk NPK Pelangiyang berbeda pada setiap perlakuan dapat meningkatkan produksi tanaman mentimun, karena semakin banyak dosis pupuk yang diberikan maka unsur hara yang tersedia bagi tanaman juga semakin banyak sehingga kesempatan untuk menyerap unsur hara semakin

\begin{tabular}{|c|c|c|c|c|c|}
\hline \multirow{3}{*}{$\begin{array}{c}\text { Perlakuan } \\
\text { NPK0 }\end{array}$} & \multicolumn{5}{|c|}{ Variabel Hasil } \\
\hline & \multicolumn{2}{|c|}{$\begin{array}{l}\text { Jumlah buah tan-1 } \\
\text { (buah) }\end{array}$} & $\begin{array}{l}\text { Panjang buah tan-1 } \\
(\mathrm{cm})\end{array}$ & \multicolumn{2}{|c|}{$\begin{array}{l}\text { Diameter buah tan-1 } \\
(\mathrm{cm})\end{array}$} \\
\hline & 3,06 & $\mathrm{e}$ & $14,35 \mathrm{e}$ & 3,97 & $\mathrm{e}$ \\
\hline NPK1 & 3,63 & d & $14,89 \mathrm{~d}$ & 4,13 & d \\
\hline NPK2 & 4,31 & $\mathrm{c}$ & $15,89 \mathrm{c}$ & 4,40 & $\mathrm{c}$ \\
\hline NPK3 & 5,25 & $\mathrm{~b}$ & $16,45 \quad b$ & 4,68 & $\mathrm{~b}$ \\
\hline NPK4 & 7,13 & $\mathrm{a}$ & $17,21 \quad \mathrm{a}$ & 5,13 & $\mathrm{a}$ \\
\hline BNT 5\% & $\mathbf{0 , 3 1}$ & & $\mathbf{0 , 3 1}$ & $\mathbf{0 , 1 5}$ & \\
\hline Perlakuan & \multicolumn{2}{|c|}{ Berat buah tan-1 $(\mathrm{g})$} & Berat buah ha- ${ }^{1}$ (ton) & & \\
\hline NPK0 & 573,63 & $\mathrm{e}$ & $22,95 \mathrm{e}$ & & \\
\hline NPK1 & 996,19 & d & $39,85 \quad d$ & & \\
\hline NPK2 & 1361,50 & $\mathrm{c}$ & 54,46 c & & \\
\hline NPK3 & 1736,81 & $\mathrm{~b}$ & $69,47 \quad b$ & & \\
\hline NPK4 & 2492,75 & $\mathrm{a}$ & $99,71 \quad \mathrm{a}$ & & \\
\hline BNT 5\% & 143,09 & & $\mathbf{5 , 7 2}$ & & \\
\hline
\end{tabular}




\section{Josina : Pengaruh Pupuk NPK Pada Tanaman Mentimun}

Hasil Sidik ragam menunjukan bahwa pada perlakuan dosis NPK2 (600kg/ha)tidak memberikan hasil yang optimal terhadap variabel Jumlah buah tan-1,panjang buah $\tan ^{-1}$, diameter buah $\tan ^{-1}$, berat buah $\tan ^{-1}$ dan berat buah ha1. Hal ini . Hal ini dapat terjadi karena kandungan unsur hara N, P dan K pada dosis perlakuan NPK2 $\left(600 \mathrm{~kg} \mathrm{ha}^{-}\right.$ $\left.{ }^{1}\right)$ tersebut hanya sedikit sekali yaitu $\mathrm{N}$ (90 kg/ha), P (90 kg/ha), K (90 kg/ha), ditambah dengan pupuk organik Petroganik 20 ton/ha yang kandungan unsur haranya $\mathrm{N}=0,40 \%, \mathrm{P}=0,10 \%$, dan $\mathrm{K}=0,10 \%$ setara dengan $\mathrm{N}=80$ $\mathrm{kg} / \mathrm{ha}, \mathrm{P}=20 \mathrm{~kg} / \mathrm{ha}$, dan $\mathrm{K}=20 \mathrm{~kg} / \mathrm{ha}$, total dari unsur hara yang diberikan adalah $\mathrm{N}=170 \mathrm{~kg} / \mathrm{ha}, \mathrm{P}=110 \mathrm{~kg} / \mathrm{ha}$, dan $\mathrm{K}=110 \mathrm{~kg} / \mathrm{ha}$, total dari unsur hara yang diberikan adalah $\mathrm{N}=170 \mathrm{~kg} / \mathrm{ha}, \mathrm{P}=110$ $\mathrm{kg} / \mathrm{ha}$, dan $\mathrm{K}=110 \mathrm{~kg} / \mathrm{hamasih}$ sangat rendah dibandingkan dengan kebutuhan unsur hara makro yang dibutuhkan oleh tanaman mentimun yaitu N (300 $\mathrm{kg} / \mathrm{ha}), \quad$ P (200 kg/ha) dan K (200 kg/ha)(Rukmana, 1994). Berbeda perlakuan dosis, $1.200 \mathrm{~kg} / \mathrm{ha}$ (NPK4) yang memberikan hasil yang paling baik karena memberikan hasil yang optimalyaitu Jumlah Buahtan ${ }^{-1} \quad(7,13$ buah),Panjang Buah $\tan ^{-1}(17,21 \mathrm{~cm})$, Diameter $\operatorname{Buahtan}^{-1}(5,13 \mathrm{~cm})$, Berat Buah tan- ${ }^{1}$ (353 gram) dan Berat Buah $\mathrm{ha}^{-1}(14,12$ ton).Hal ini disebabkan oleh jumlah kandungan unsur hara yang terdapat dalam pupuk NPK Pelangi dengan dosis 1.200 tonha $^{-1}$ dimana unsur hara N (180 kg/ha), P (180 kg/ha) dan K (180 kg/ha), ditambah pupuk organik petroganik 20 ton/ha yang kandungan unsur haranya $\mathrm{N}=0,40 \%, \mathrm{P}=0,10 \%$, dan $\mathrm{K}=0,10 \%$ setara dengan $\mathrm{N}=80$ $\mathrm{kg} / \mathrm{ha}, \mathrm{P}=20 \mathrm{~kg} / \mathrm{ha}$, dan $\mathrm{K}=20 \mathrm{~kg} / \mathrm{ha}$, total dari unsur hara yang diberikan adalah $\mathrm{N}=260 \mathrm{~kg} / \mathrm{ha}, \mathrm{P}=200 \mathrm{~kg} / \mathrm{ha}$, dan $\mathrm{K}=200 \mathrm{~kg} / \mathrm{ha}$ dapat memenuhi kebutuhan akan unsur hara tanaman mentimun, dimana kebutuhan unsur hara tanaman mentimun yaitu $\mathrm{N}: 300$ kg/ha, P: 200 kg/ha dan K: 200 kg/ha (Rukmana, 1994).Peranan unsur hara makro yang terkandung pupuk NPKPelangi mempunyai fungsi masingmasing dalam proses metabolismetumbuhan. Mulyani (2002), menyatakan bahwa unsur Nberperan dalam pembentukan klorofil yang berguna dalam proses fotosintesis,dimana apabila fotosintesis lancar maka semakin banyak pula karbohidrat yangakan dihasilkan.

Menurut Lubis (2004), unsur P berperan sebagaibahan dasar pembentukan protein untuk menghasilkan energi ATP dan ADP,dimana energi ini dibutuhkan dalam proses metabolisme untuk pembentukanasam amino, tepung, lemak dan senyawa organik lainnya. Sedangkan unsur Kberperan membantu pembentukan protein dan karbohidrat sekaligus memperkuattubuh tanaman seperti daun, bunga dan buah sehingga tidak mudah gugur. Selainitu unsur K juga dapat meningkatkan kualitas hasil buah (rasa dan warnanya).

\section{SIMPULAN}

Berdasarkan hasil penelitian dengan pemberian pupuk NPK Pelangi terhadap tanaman mentimun (Cucumis sativusL.) dapat disimpulkan bahwa :
1. Pemberian
pupuk
NPK Pelangipada tanaman mentimun 
berpengaruh sangat nyataterhadap prosentase peningkatanjumlah daun $(11,89 \%)$, luas daun ${ }^{-1}(12,85$ $\%)$, jumlah buah $\tan ^{-1}(26,37 \%)$, panjang buah $\tan ^{-1}(4,42 \%)$, diameter buah $\tan ^{-1}(8,77 \%)$, berat buah $\tan ^{-1}(30,33 \%)$, berat buah ha- ${ }^{-1}(30,33 \%)$.

2. Dosis optimum pupuk NPK Pelangi adalah $1.200 \mathrm{~kg} / \mathrm{ha}$ karena memberikan pertumbuhan dan hasil yang optimal padajumlah daun $\left(15,13\right.$ helai)luas daun ${ }^{-1}$ $\left(420,69 \mathrm{~cm}^{2}\right)$, jumlah buah $\tan ^{-1}$ (7,13 buah ), panjang buah $\tan ^{-1}$ $(17,21 \mathrm{~cm})$, diameter buah $\tan ^{-1}$ $(15,13 \mathrm{~cm})$, berat buah $\tan ^{-1}$ (2492,75 gram),

berat buah $\mathrm{ha}^{-1}(99,71$ ton

\section{UCAPAN TERIMA KASIH}

Pada kesempatan ini penulis ingin mengucapkan terima kasih kepada semua pihak yang telah membantu dengan caranya masing-masing dalam melengkapi tulisan ini.

\section{DAFTAR PUSTAKA}

Badan Pusat Statistik dan Direktorat Jenderal Hortikultura 2015.Produktivitas Sayuran di Indonesia. .

Dinas Pertanian Tanaman Pangan dan Hortikultura Kabupaten Ende tahun 2015.Data Luas Tanam, Luas Panen, Produksi dan Produktifitas Tanaman Hortikultura.

Dinas Pertanian Tanaman Pangan dan Hortikultura NTT 2015.Data Luas Tanam, Luas Panen, Produksi dan Produktifitas Tanaman Hortikultura.

Ga'a, G. Inarno, 2014. Pengaruh Pemberian Pupuk Cair Teh Kompos
Terhadap Pertumbuhan dan Hasil Tanaman Sawi Hijau (Brassica juncea L.). Skripsi Fakultas Pertanian Universitas Flores

Gardner, F.P., R.B. Peace dan R.L. Mitchell., 1991. Fisiologi Tanaman. Gadjah Mada Universty Press. Yogyakarta.

Gomez, K.A, A.A. 2007. Prosedur Statistik Untuk Penelitian Pertanian.Edisi ke 2. Jakarta: Universitas Indonesia.

Lingga, P, 2003. Fisiologi Pertumbuhan dan Perkembangan Tanaman. Raja Grafindo Persada. Jakarta.

Lubis, 2004 : 47. "Pengaruh pemberian Gibberellin (GA3) dan pupuk majemuk NPK terhadap pertumbuhan dan produksi terung (solanum melongena L.”. SKRIPSI : Dipublikasikan, Jurusan Budidaya Pertanian FakultasPertanian Universitas Sumatera Utara 2004.

Mulyani, 2002. Peranan Pupuk Nitrogen, Phosfor dan Kalium Terhadap Tanaman Sayuran. Sinar Baru Algesindo. Bandung.

Paian Simanungkalit dkk (2013) : 6 "Respons pertumbuhan dan produksi tanaman Melon (cucumis melo L.) terhadap pemberian pupuk NPK danpemangkasan buah" . JURNAL : Program Studi Agroekoteknologi,Fakultas Pertanian, USU, Medan 2013.

PT. Pupuk Kaltim. 2005. NPK PELANGI.

http://www.pupukkaltim.com. Diaksespada tanggal 27 Maret 2015. 


\section{Josina : Pengaruh Pupuk NPK Pada Tanaman Mentimun}

Rukmana, R., 1994. Budidaya Mentimun. Kanisius.Yogyakarta.

Saeri Mohamad dan Suwono 2012 "Kajian efektivitas pupuk N.P.K pelangi 15:15:15 dalam upaya penigkatan hasil dan pendapatan petani jagung dilahan kering kabupaten Tuban" . Jurnal : Dipublikasikan, FakultasPertanian Universitas Trunojoyo Madura 2012. Hal 17.

Sumpena, 2001. Kiat Bercocok Tanam Sayuran Organik. Lembaga Sehat Dompet Dhuafa Republika
Sunarjono, H, H. 2007. Pengaruh Pupuk Majemuk NPK Pelangi terhadap Pertumbuhan dan Hasil Jagung (Zea mays L) di Tanah Inceptisols. Jurnal Tanah dan Iklim No. 23. Hal 78.http://jurnal.usu.ac.id/index.p hp/agroekoteknologi/article/dow nload/540/462[8 Maret 2016].

Suwarno, V. Salsabila.2013 Respon Pertumbuhan dan Produksi Tanaman Mentimun (Cucumis sativus L.) Melalui Perlakuan Pupuk NPK Pelangi. Fakultas Pertanian. Uniersitas Negeri Gorontalo. 